\title{
EFEK SELF-EFFICACY TERHADAP READINESS FOR CHANGE MASYARAKAT SAMOSIR DALAM MENYAMBUT BALI BARU
}

\author{
Wilbert $^{1}$, Christine Tandriani ${ }^{2}$, Winnie Gozalie ${ }^{3}$, Rianda Elvinawanty ${ }^{4}$ \\ ${ }^{1}$ Fakultas Psikologi, Universitas Prima Indonesia, Medan, Indonesia, Email:wilbert.huang46@gmail.com
}

\begin{abstract}
ABSTRAK
Histori Artikel

Dalam meningkatkan pariwisata Indonesia, Pemerintah Indonesia meluncurkan program Bali Baru dimana Danau Toba dengan bantuan Samosir diprioritaskan untuk menjadi Bali Baru. Namun, ada beberapa

Submitted:

2 Juli 2021

Reviewed:

10 Juli 2021

Accepted:

10 Agustus 2021

Published:

15 November 2021 permasalahan yang terjadi yaitu terkait permasalahan sumber daya manusia (SDM) masyarakat Samosir yang dimana ada perilaku mereka menunjukkan bahwa mereka belum siap untuk berubah menjadi Bali Baru. Ada beberapa faktor yang mempengaruhi readiness for change ini yang salah satunya ialah self-efficacy. Untuk mengetahui kebenaran ada tidaknya hubungan antara kedua variabel tersebut, dengan berlandas pada data berjumlah 383 masyarakat Samosir dan menggunakan metode deskriptif kuantitatif, penelitian ini bertujuan untuk melihat apakah terdapat hubungan dan seberapa besar sumbangan antara self-efficacy terhadap readiness for change pada masyarakat Samosir. Data yang diperoleh menggunakan skala akan diuji dengan menggunakan korelasi Pearson Product Moment melalui bantuan IBM SPSS Statistics 22 untuk menguji hipotesis yang mana hasil penelitian menunjukkan hipotesis diterima yaitu adanya hubungan positif antara self-efficacy dengan readiness for change.
\end{abstract}

Kata Kunci: Bali Baru, readiness for change, self-efficacy, Masyarakat Samosir

\section{SELF-EFFICACY EFFECT ON PEOPLE OF SAMOSIR ISLAND'S READINESS FOR CHANGE IN WELCOMING NEW BALI}

\begin{abstract}
To improve Indonesian tourism, The Indonesian Government have launched the New Bali program where Lake Toba with the support of Samosir Island be prioritize to become New Bali. However, there have been some issues that happen, the problem is about Human Resource problem where the behavior of people in Samosir Island show that they are still not ready to change into New Bali. There are some factors that influence readiness for change, where one of them is self-efficacy. To find out the truth of whether or not there is a relationship between the two variables, based on data from 383 people of Samosir Island and using descriptive quantitative methods, this study aims to see if there is a relationship and how much contribution between self-efficacy to readiness for change in people of Samosir Island. The data obtained using the scale will be tested using Pearson Product Moment Correlation through the help of IBM SPSS Statistics 22 to test the hypothesis that the results of the study showed that hypothesis is accepted it means that there is a positive relationship between self-efficacy and readiness for change.
\end{abstract}

Keywords : New Bali, readiness for change, self-efficacy, people of Samosir Island 


\section{PENDAHULUAN}

Kehidupan manusia sering sekali dipenuhi dengan kesibukkan dan masalah-masalah yang tidak pernah berhenti, maka tidak heran manusia akan mengalami yang namanya frustrasi, stress ataupun depresi. Alangkah baiknya bila kita menyisihkan sedikit dari waktu kita untuk berpariwisata, berjalan, atau hanya sekedar memandangi pemandangan alam yang telah diciptakan oleh Sang Pencipta untuk menenangkan diri.

Dunia sudah tidak heran lagi dengan pariwisata yang telah menjadi industri terbesar, dimana sektor pariwisata ini mempunyai pengaruh yang terbilang besar terhadap perekonomian di suatu negara. Pariwisata sendiri bisa didefinisikan sebagai kegiatan proses, kegiatan, dan hasil yang timbul dari hubungan serta interaksi antara wisatawan, suppliers kebutuhan kegiatan pariwisata, pemerintah, masyarakat lokal, dan lingkungan sekitar yang terlibat dalam menarik perhatian serta menjadi hosting dalam pariwisata tersebut (Goeldner \& Ritchie, 2009). Industri pariwisata ini memiliki fungsi utama yaitu melayani turis yang datang dengan menyediakan jasa pariwisata yang diharapkan dapat memberikan pengalaman yang positif kepada turis ketika berkunjung (Camilleri, 2018). Maka dari itu industri pariwisata ini dibutuhkan perihal seperti memberi kenyaman kepada turis selama berkunjung, layanan yang terpercaya dan efisien, fasilitas transportasi yang teratur, serta fasilitas akomodasi yang baik dengan standar yang tinggi, termasuk disini dalam perihal catering (Jafari, dalam Camilleri, 2018). Industri pariwisata ini berorientasi pada kegiatan menghasilkan barang ataupun jasa untuk memenuhi kebutuhan para wisatawan dalam melangsungkan pariwisata (PP No.50/2011).

Tidak kalah dengan beberapa destinasi favorit yang terkenal seperti Tokyo, Seoul, Melbourne, Maldives, Phuket, Singapura, Bangkok, Swiss, Norwegia, dan beberapa negara lainnya. Indonesia sendiri memiliki keindahan alam serta tradisi atau budaya yang kaya dan sangat melimpah dari Sabang sampai Merauke. Hal ini membuat para wisatawan juga tertarik untuk berlibur ke Indonesia. Salah satu provinsi yang banyak dikunjungi oleh turis domestik maupun turis mancanegara adalah Provinsi Sumatera Utara.

Provinsi Sumatera Utara menyimpan tempat wisata yang cukup berlimpah dan sangat menarik untuk dikunjungi. Salah satunya adalah Danau Toba yang sudah menjadi ikon wisatawan di Sumatera Utara. Bukan hanya di Danau Toba saja, kebanyakan wisatawan juga mengunjungi pulau Samosir yang terletak di tengah perairan Danau Toba. Pemandangan yang memukaukan mata, Potensi alam pada beberapa daerah, iklim yang sejuk, posisi yang tergolong strategis di kawasan Danau Toba, berlimpahnya potensi budaya dan tradisi lokal yang terhampar di dalamnya sehingga cocok untuk para wisata budaya, serta beberapa hal lain lagi yang merupakan kekuatan sehingga menjadikan daya tarik tersendiri bagi Samosir di mata para wisatawan (Pujiono, Agustono \& Aulia, 2018).

Berdasarkan data kunjungan wisatawan ke Samosir yang diperoleh dari berita media online Kompas.com dan Medanbisnisdaily.com, tercatat bahwa dari tahun 2016 jumlah wisatawan baik nusantara maupun mancanegara terus meningkat. Bahkan pada tahun 2020 dimana dunia sedang terserang wabah virus corona atau Covid-19, wisatawan yang datang pun meningkat dari tahun lalu, jika dibandingkan 2019 lalu pada bulan Februari, jumlah wisatawan yang datang sebanyak 72.000. sedangkan Pada bulan Februari 2020, telah mencapai 73.000 orang.

Perkembangan pengunjung yang sangat bagus tersebut membuat Danau Toba sekaligus Samosir menjadi destinasi yang diprioritas oleh pemerintah yang dimana akan dikembangkan menjadi "Bali Baru". Dengan kelebihan yang dimiliki oleh Samosir, Danau Toba sangat diuntungkan, didorong dan sangat berpotensi menjadi "Bali Baru". Segala hal telah disiapkan dan dilaksanakan untuk mencapai tujuan 
membentuk "Bali Baru" dan direncanakan dalam kurun waktu 5 (lima) tahun yang akan datang, Danau Toba akan menjadi "Bali Baru". Pembangunan dari segi infrastruktur dan atraksi sudah sangat memadai untuk dinikmati pengunjung terutama wisatawan mancanegara (lifestyle.kontan.co.id).

Dalam sebuah berita yang diunggah oleh cnbcindonesia.com yang berjudul "Pengembangan 10 'Bali Baru', Jokowi Sebut 6 Kendala Utama" disebutkan ada 6 kendala dalam menuju Bali Baru yaitu adanya permasalahan pengaturan dan pengendalian tata ruang, masalah akses konektivitas menuju destinasi wisata, permasalahan fasilitas, permasalahan sumber daya manusia (SDM), permasalahan produk yang ada, dan terakhir permasalahan promosi. Dari keenam kendala tersebut, permasalahan SDM sangat melekat dengan masalah yang sedang dihadapi di Samosir. Menurut Jokowi, SDM yang berkualitas akan berpengaruh terhadap budaya kerja, budaya melayani, dan budaya kebersihan suatu pariwisata. Budaya kebersihan inilah yang sedang dipermasalahkan di Samosir yaitu kebersihan yang tidak terjaga dengan adanya pembuangan sampah sembarangan. Dalam sebuah video yang beredar di aplikasi Instagram (www.instagram.com) dengan judul "Peduli Samosir?" dan berdurasi 1 menit 27 detik yang diunggah oleh akun @ebenezer_2 terlihat dalam video tersebut tumpukan sampah yang dibuang oleh masyarakat Samosir di hutan Ronggurnihuta. Pembuangan sampah tersebut menunjukkan bahwa pemikiran masyarakat Samosir masih perlu ditingkatkan untuk membuang sampah pada tempatnya khususnya para SDM di Samosir yang berperan penting dalam menarik wisatawan. Warga masyarakat juga harus mempertahankan kontrol pengembangan pariwisata dengan terlibat dalam menentukan visi pariwisata masyarakat, mengidentifikasi sumber daya yang harus dijaga dan ditingkatkan, dan mengembangkan tujuan dan strategi untuk pengembangan pariwisata dan manajemen. Warga masyarakat seharusnya ikut berpartisipasi dalam pelaksanaan strategi pengembangan

pariwisata

serta pengoperasian infrastruktur pariwisata, pelayanan, dan fasilitas.

Bukan hanya permasalahan mengenai sampah saja, berdasarkan berita di media kompas.com yang berjudul "Viral Tagihan Restoran Rp 1,6 Juta di Samosir, Pemilik: Biaya untuk Puluhan Orang", ternyata ada terjadi monopoli harga, kebanyakan barang yang diperjual di Samosir bisa dikategorikan terlalu mahal dan diatas harga normal. Padahal di daerah asal wisatawan, barang tersebut dijual murah, hal ini membuat kebanyakan wisatawan merasa seperti ditipu yang akhirnya menyebabkan kurang puasnya wisatawan selama berkunjung di Samosir.

Pelayanan yang kurang ramah juga menjadi permasalahan, hal ini terlihat dari reaksi pengunjung setelah berwisata di Samosir. Berdasarkan review wisatawan di website Agoda (www.agoda.com), pada Samosir Cottages, salah satu hotel di Samosir, kebanyakan reviewer menulis bahwa pelayanan hotel sangat kurang ramah, hal ini dijelaskan oleh reviewer Darwin, dimana pelayanan hotel yang kurang ramah dilakukan dengan membanting serta tidak memakai seragam yang formal yang terkesan tidak sopan. Tidak hanya Darwin saja kebanyakan reviewer juga menulis demikian, staff tidak ramah serta pelayanan yang terkesan tidak siap melayani pengunjung, seharusnya para staff sudah siap melayani pengunjung. Selain itu, fasilitas yang kurang memuaskan terlihat dari review hotel Lekjon Cottage, seorang wisatawan bernama Andrew menulis bahwa fasilitas hotel kurang terawat. Bahkan ada wisatawan yang sampai menulis bahwa hotel tersebut tidak pantas disebut hotel dengan fasilitas yang ada, review ini dilakukan oleh LIM seorang wisatawan asal Malaysia. Hanya 2 (dua) hotel saja tapi sudah mendapatkan kritik seperti itu.

Permasalahan - permasalahan yang disebutkan paragraf sebelumnya menunjukkan bahwa masyarakat Samosir belum memiliki kesiapan untuk berubah menyesuaikan diri dengan perubahan yang 
diinginkan dalam menyukseskan program "Bali Baru". Jika dibiarkan maka program "Bali Baru" ini bisa saja gagal. Oleh karena itu, kesiapan masyarakat untuk berubah (readiness for change) sangat dibutuhkan untuk menyukseskan program Bali Baru.

Secara teoritis, readiness for change merupakan suatu reaksi terhadap suatu perubahan, dimana individu tersebut mempunyai kepercayaan diri atas kemampuannya untuk mengatasi perubahaan tersebut (Vakola, dalam Metwally, et. al., 2019). Vodka (dalam Metwally, et. al., 2019), mengatakan bahwasannya individu siap untuk berubah ketika individu tersebut "mulai atau terus menerus terlibat dalam suatu perilaku yang terkait perubahan tersebut seperti mendukung dan berpartisipasi dalam perubahaan yang ada", yang mana diperlukan adanya kepercayaan pada kemampuannya sendiri untuk sukses dalam perubahan tersebut. Lanjutnya, readiness for change ini dikonseptualisasikan sejauh mana individu memiliki kepercayaan pada kemampuannya sendiri untuk sukses dalam perubahan, dan secara psikologis atau fisik siap atau bersedia untuk berpartisipasi ikut dan terlibat dalam membuat perubahaan tersebut berhasil.

Siap tidaknya berubah suatu individu bisa terlihat dari pikiran, perasaan, dan niat individu tersebut, yang mungkin saja mengarah kepada suatu perilaku tertentu yang terkait dengan sikapnya (Desplaces, 2005). Holt et al. (2007) juga mengungkapkan hal yang senada bahwasannya readiness for change didefinisikan sebagai sikap komprehensif yang dipengaruhi secara bersamaan oleh isi (yaitu, apa yang sedang diubah), proses (yaitu, bagaimana perubahan tersebut diimplementasikan), konteks (yaitu, keadaan dimana perubahan itu terjadi) dan individu (yaitu, karekteristik mereka yang diminta untuk diubah) yang terlibat. Selain itu lanjutnya, readiness for change suatu individu secara kolektif mencerminkan sejauh mana individu atau kelompok baik secara kognitif dan emosional cenderung mau menerima, menganut, dan mengadopsi rencana tertentu dengan sengaja supaya mengubah status quo saat ini.

Dari definisi di atas memperkuat bukti bahwa masyarakat Samosir belum siap untuk menghadapi perubahan menuju Samosir yang lebih baik, terlihat dari ketidakpedulian masyarakat setempat pada masalah sampah dengan membuang limbah domestik dan limbah cair ke badan air Danau Toba, sikap masyarakat yang kurang ramah, maupun sikap pedagang yang mematok harga yang fantastis.

Readiness for Change suatu individu dipengaruhi oleh berbagai faktor. Studi literatur yang dilakukan oleh Holt, et. al. (2007), ia melihat bahwasannya ada 5 (lima) faktor yang paling mempengaruhi readiness for change, yaitu discrepancy (yaitu keyakinan bahwa perubahan diperlukan), self-efficacy (yaitu keyakinan diri bahwa perubahan dapat dilaksanakan), organizational valence (yaitu keyakinan bahwa perubahan itu akan bermanfaat secara organisasi atau kelompok), management support (yaitu keyakinan bahwa pemimpin kelompok/organisasi berkomitmen pada perubahan), dan personal valence (yaitu keyakinan bahwa perubahan itu akan bermanfaat secara pribadi). Atas faktor tersebut, self-efficacy diyakini mempunyai pengaruh yang cukup kuat terhadap readiness for change seseorang.

Efikasi diri atau self-efficacy sendiri didefinisikan sebagai salah satu kemampuan suatu individu dalam meregulasi dirinya. Self-efficacy bisa diartikan sebagai persepsi akan kemampuannya untuk mengatur diri dan mengimplementasikan suatu tindakan tertentu yang diperlukan untuk menghasilkan suatu kinerja (Bandura, dalam Eliyana, et. al., 2005), dan dalam mencapai hasil yang diinginkan (Bandura, dalam Luszczynska, Scholz, \& Schwarzer, 2005). Self-efficacy ini mencerminkan keyakinan suatu individu bahwasannya individu tersebut memiliki kapasitas untuk mencapai tujuan yang dikehendaki dalam situasi tertentu (Bandura, dalam Desplaces, D., 2005). 
Dalam sebuah penelitian berjudul "Berubah, Siapa Takut? Pengaruh Efikasi Diri Terhadap Kesiapan Untuk Berubah Pada Karyawan Di PT TP Tangerang" yang dilakukan oleh Angkawijaya et al. (2017) menunjukkan bahwa ada pengaruh yang signifikan antara efikasi diri terhadap kesiapan untuk berubah yaitu sebesar $14.4 \%(\mathrm{~F}=11.066 ; \mathrm{p}=.001 ; \mathrm{p}$ $<.05)$. Hasil yang serupa juga didapat oleh Eliyana, et al. (2016), ada pengaruh yang signifikan antara self-efficacy dengan readiness for change sama seperti pernyataan Holt (2008) dengan hasil t-hitung lebih besar dari t-tabel $(2.251>1.96)$ yang menunjukkan hipotesis diterima.

Berdasarkan uraian di atas, maka guna menyukseskan program atau perencanaan "Bali Baru", perlu untuk mengamati apakah self-efficacy seseorang mempengaruhi readiness for change suatu individu. Peneliti merumuskan hipotesis yaitu adanya hubungan yang positif antara self-efficacy dan readiness for change pada masyarakat Samosir.

\section{LITERATUR REVIEW}

\section{Readiness for Change dalam Pariwisata}

Perkembangan sektor pariwisata ada menimbulkan beberapa dampak yang mungkin bagi masyarakat setempat perihal perubahan tersebut merupakan dampak negatif bagi mereka. Perubahan yang ada mungkin saja dikarenakan bertentangan dengan kehidupan sosial, agama, budaya ataupun pola hidup masyarakat setempat (Urbanus \& Febianti, 2017). Tidak semua perencanaan perubahaan akan sukses, mengingat tidak semua individu bisa menerima perencanaan perubahan tersebut (Darmawan \& Azizah, 2020). Tidak semua individu akan bereaksi secara positif terhadap perubahan, beberapa akan menunjukkan reaksi negatif dalam perilaku mereka yang menandakan mereka belum siap untuk berubah (Piderit, dalam Darmawan \& Azizah, 2020). Hal ini mungkin saja dikarenakan mereka sudah terbiasa atau merasa aman berada di comfort zone mereka dan takut akan resiko jika keluar dari zona aman tersebut sehingga membuat mereka tidak siap untuk berubah. Ada beberapa faktor yang mempengaruhi readiness for change ini yang sudah dijelaskan diatas dimana salah satu faktornya menurut Holt, et. al. (2007) adalah self-efficacy.

\section{Self-Efficacy kaitannya dengan Readiness for Change}

Banyak studi yang sudah meneliti bahwasannya self-efficacy mempunyai hubungan dengan readiness for change. Untuk membangun perasaan suatu individu untuk siap menerima perubahaan, langkah pertama yang perlu dilakukan ialah membangun self-efficacy seseorang untuk mau berubah (Bernerth, dalam Fatima, Riaz, \& Mahmood, 2020). Semakin tinggi tingkat self-efficacy, itu akan berefek terhadap readiness for change individu tersebut (Emsza et al., dalam dalam Fatima, Riaz, \& Mahmood, 2020).

\section{METODE}

Penelitian ini dilakukan untuk mengetahui hubungan antara self-efficacy dengan readiness for change pada masyrakat Samosir dengan menggunakan instrumen berupa skala Likert yang akan dibagikan kepada masyarakat sekitar Samosir, yaitu pertama skala readiness for change dengan realibilitas skala sebesar 0.977 yang terdiri atas 36 aitem.

Skala pengukuran readiness for change disusun berdasarkan teori Holt, et. al. (2007) yang menyatakan bahwa dimensi readiness for change meliputi appropriateness (mengacu kepada ia merasa bahwa itu adalah pilihan tepat ketepatan untuk melakukan perubahan), change efficacy (mengacu pada sejauh mana ia merasa memiliki keterampilan atau tidak untuk dapat melaksanakan tugas dan kegiatan yang terkait dengan pelaksanaan perubahan tersebut), management support (mengacu pada sejauh mana atasan dan mendukung atau tidak terkait pelaksanaan perubahan tersebut), dan personal benefit (mengacu 
pada sejauh mana ia akan mendapatkan manfaat dari perubahan tersebut).

Kedua adalah skala self-efficacy dengan realibilitas skala sebesar 0.965 yang terdiri atas 37 aitem. Skala pengukuran self-efficacy disusun dengan menggunakan teori Bandura (1997) dengan dimensi efikasi diri yang terdiri dari level/magniture (tingkat kesulitan tugas), strength (kemantapan keyakinan), dan generality (luas bidang perilaku).

Populasi dalam penelitian ini adalah seluruh penduduk Kabupaten Samosir yang berasal dari 9 Kecamatan sebanyak 126.118 jiwa penduduk. Merujuk pada penentuan sampel Issac dan Michael dengan taraf kesalahan pada penelitian ini sebesar 5\%, maka sampel yang didapatkan untuk penelitian ini adalah berjumlah 383 jiwa penduduk.

Penelitian dilaksanakan dengan membagikan skala kepada 383 penduduk Samosir di Kecamatan Simanindo, Kecamatan Panguruan dan Kecamatan Harian. Metode dalam penelitian ini menggunakan pendekatan deskriptif kuantitatif. Pengujian yang digunakan adalah asumsi klasik yang mencakup pengujian normalitas dan linieritas, pengujian hipotesis, serta akan diuji juga seberapa besar pengaruh selfefficacy ini terhadap readiness for change melalui pengujian koefisien determinasi.

\section{HASIL DAN PEMBAHASAN}

Sebelum melakukan analisis korelasi Pearson Product Moment menggunakan bantuan aplikasi IBM SPSS Statistics 22 untuk mengetahui hubungan antara Self Efficacy terhadap Readiness for Change pada masyarakat Samosir. Maka, terlebih dahulu dilakukan uji asumsi untuk mengetahui ada tidaknya penyimpangan data yang diperoleh dari alat pengumpul data. Uji asumsi yang digunakan dalam penelitian ini adalah uji normalitas dan uji linearitas.

\section{Hasil Penelitian}

\section{Uji Normalitas}

Tabel 1. Hasil Uji Normalitas (One KolmogorovSmirnov)

\begin{tabular}{|c|c|c|c|c|c|}
\hline Variabel & SD & $\begin{array}{l}\text { KS- } \\
\mathrm{Z}\end{array}$ & Sig. & $\mathbf{P}$ & $\begin{array}{l}\text { Keter } \\
\text { angan }\end{array}$ \\
\hline $\begin{array}{l}\text { Readiness } \\
\text { for } \\
\text { Change }\end{array}$ & 8.884 & $\begin{array}{l}1.38 \\
9\end{array}$ & $\begin{array}{l}0.32 \\
1\end{array}$ & $p>0.05$ & $\begin{array}{l}\text { Sebara } \\
\mathrm{n} \\
\text { normal }\end{array}$ \\
\hline $\begin{array}{l}\text { Self- } \\
\text { Efficacy }\end{array}$ & $\begin{array}{l}15.18 \\
4\end{array}$ & $\begin{array}{l}2.50 \\
4\end{array}$ & $\begin{array}{l}0.26 \\
5\end{array}$ & $p>0.05$ & $\begin{array}{l}\text { Sebara } \\
\mathrm{n} \\
\text { normal }\end{array}$ \\
\hline
\end{tabular}

Sumber: Hasil Penelitian, 2021 (Data diolah)

Uji normalitas sebaran data dengan menggunakan One-Sample Kolmogorov Smirnov Test, menampilkan hasil dimana variabel readiness for change dan selfefficacy mempunyai nilai signifikan yang dihasikan lebih besar dari 0,05 yaitu 0.321 untuk readiness for change dan 0.265 pada variabel self-efficacy, sehingga bisa disimpulkan bahwa sebaran data dalam penelitian ini terdistribusi normal.

Selanjutnya akan dilakukan uji linearitas untuk melihat distribusi data penelitian yaitu melihat variable bebas dalam penelitian ini mempunyai pengaruh linear atau tidak pada variabel terikat dalam penelitian ini.

\section{Uji Linearitas}

Tabel 2. Hasil Uji Linearitas Hubungan

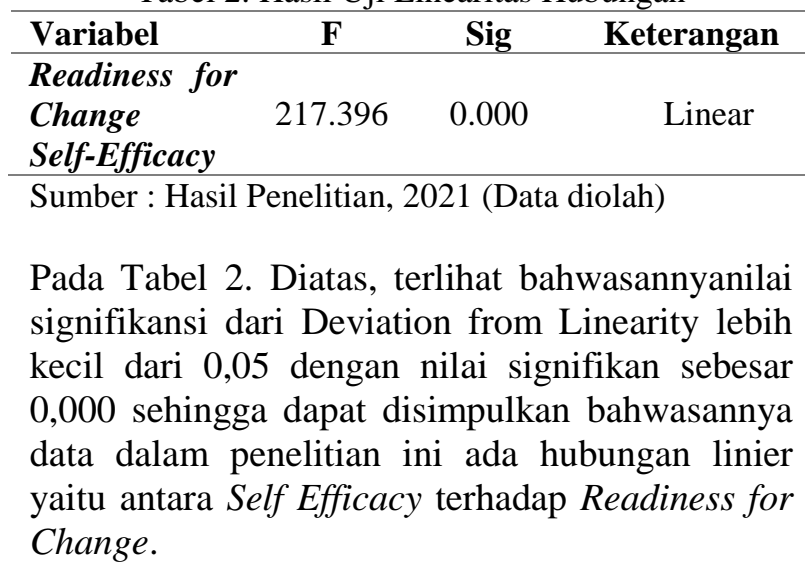

Setelah melakukan uji asumsi diatas dan uji asumsi sudah diterima, selanjutnya akan dilakukan uji hipotesis. Hipotesis dalam penelitian ini adalah terdapat hubungan positif antara self-efficacy dan readiness for change pada masyarakat Samosir. Berdasarkan hipotesa 
penelitian ini maka dilakukan uji Pearson Correlation.

\section{Uji Hipotesis}

Tabel 3. Korelasi antara Self-Efficacy dengan Readiness for Change

\begin{tabular}{rcc}
\hline Analisis & Pearson Correlation & Signifikansi (p) \\
\hline $\begin{array}{c}\text { Ko } \\
\text { relasi }\end{array}$ & 0.596 & 0.000 \\
\hline
\end{tabular}

Sumber : Hasil Penelitian, 2021 (Data diolah)

Berdasarkan tabel di atas, dapat diketahui bahwa hasil analisis korelasi diperoleh koefisien korelasi product moment sebesar 0.596 dengan nilai signifikansi dari Self Efficacy dan Readiness for Change memiliki nilai signifikansi di bawah 0,05 yaitu 0.000 sehingga dengan demikian, kedua variabel memiliki korelasi yang positif.

Tabel 4. Model Summary Sumbangan Efektif

\begin{tabular}{rccccc}
\hline Model & R & $\begin{array}{c}\boldsymbol{R} \\
\text { Square }\end{array}$ & $\begin{array}{c}\text { Adjusted } \\
\boldsymbol{R} \text { Square }\end{array}$ & $\begin{array}{c}\text { Std. Error } \\
\text { of the } \\
\text { Estimate }\end{array}$ \\
\hline 1 & $596^{\mathrm{a}}$ & .355 & .354 & 7.143 \\
\hline
\end{tabular}

Sumber : Hasil Penelitian, 2021 (Data diolah)

Berdasarkan pada tabel di atas terlibat bahwasannya nilai koefisien determinasi $R$ Square sebesar 0,355. Hal ini menunjukkan bahwa kemampuan variabel self-efficacy menjelaskan pengaruhnya terhadap readiness for change sebesar 35,5\%. Sedangkan sisanya dipengengaruhi oleh berbagai variabel lainnya yang tidak diteliti oleh peneliti.

\section{Pembahasan}

Berdasarkan paparan hasil diatas, diketahui bahwa Hasil penelitian pada 383 responden yaitu masyarakat Samosir yang menjadi subjek penelitian diperoleh hasil bahwa terdapat hubungan yang positif dan signifikan antara self-efficacy terhadap readiness for change dengan nilai Pearson Correlation sebesar $\mathrm{r}=0,596$ dan Sig sebesar $0.000(\mathrm{p}<0.05)$, artinya semakin tinggi selfefficacy suatu individu maka semakin tinggi juga readiness for change dan sebaliknya semakin rendah self-efficacy maka semakin rendah readiness for change individu tersebut..
Penjelasan di atas sesuai dengan pendapat yang diungkapkan oleh Cunningham (2002) yang menyatakan bahwa seseorang yang memiliki self-efficacy yang tinggi terhadap perubahan dan mengkontribusikan dirinya terhadap perubahan tersebut maka akan memudahkan terjadinya perubahan yang diinginkan. Semakin tinggi kepercayaan seseorang untuk bisa menyelesaikan masalah dikarenakan perubahan tersebut atau dengan kata lain efikasi diri individu tersebut tinggi, maka semakin mudah individu tersebut menerima suatu perubahan yang sudah direncanakan dan akan dilakukan.

Hasil penelitian ini sekata dengan penelitian yang dilakukan oleh Angkawijaya et al. (2017) terhadap 68 karyawan PT TP. Hasil penelitian mereka menunjukkan bahwasannya efikasi diri ini memiliki pengaruh yang signifikan terhadap kesiapan untuk berubah yaitu sebesar $14.4 \%(\mathrm{~F}=$ 11.066; $\mathrm{p}=.001 ; \mathrm{p}<.05)$. Hasil yang serupa juga didapat oleh Eliyana et al. (2016) dalam penelitiannya terhadap karyawan PT Pos Indonesia, dimana penelitian mereka senada dengan pernyataan Holt (2008) yaitu adanya pengaruh yang signifikan antara self-efficacy dengan readiness for change dengan t-hitung lebih besar dari t-tabel $(2.251>1.96)$ yang menunjukkan hipotesis mereka diterima.

Pada penelitian ini juga diperoleh koefisien determinasi $R$ Square $\left(\mathrm{R}^{2}\right)$ sebesar 0.355 . berdasarkan hasil tersebut dapat disimpulkan bahwa ada sumbangan efektif dari selfefficacy sebesar 35.5 persen yang mempengaruhi readiness for change pada masyarakat Samosir, dan sisanya 64.5 persen dipengaruhi oleh faktor lain yang tidak diteliti oleh peneliti.

Pada pelaksanaan penelitian, adapun alasan kenapa peneliti memilih Kecamatan Simanindo ialah karena dalam menuju ke Kabupaten Samosir jikalau menggunakan jalur laut yaitu menyeberangi Danau Toba dengan kapal feri, Kecamatan Simanindo inilah yang akan menjadi target destinasinya kebanyakan wisatawan pada umumnya. Selain jalur laut ada juga jalur darat yaitu melalui Jalan Tele yang tentunya akan 
melewati Kecamatan Harian dan biasanya beberapa wisatawan akan berhenti menikmati objek wisata yang ada di Kecamatan Harian. Terakhir, untuk dipilihnya Kecamatan Panguruan ialah karena merupakan kecamatan dimana ibu kota daripada Kabupaten Samosir terletak. Ketiga kecamatan tersebut dipilih karena sudah dipertimbangkan peneliti bahwasannya wisatawan akan selalu melewati ketiga kecamatan tersebut yang pastinya masyarakat disekitar daerah tersebut akan lebih terkena dampak daripada perubahan pariwisata yang akan terjadi jika program Bali Baru berhasil. Oleh karena itu, menurut peneliti sampel ketiga kecamatan tersebut bisa mewakili populasi serta tepat untuk melihat tingkat readiness for change serta self-efficacy mereka sehingga itulah peneliti memilih ketiga Kecamatan tersebut.

Selain itu, pelaksanaan penelitian yang dilakukan peneliti pada masyarakat Samosir secara umum terlihat bahwa masyarakat Samosir ini memiliki tingkat readiness for change yang tergolong cukup bagus. Hal ini diketahui dari hasil observasi peneliti dimana peneliti melihat bahwa Kabupaten Samosir ini sedang menggalakkan pembangunan demi menyukseskan berjalannya program Bali Baru, yaitu adanya perbaikan fasilitas seperti perbaikan jalan, pembangunan pelabuhan baru, mulai dibangun lampu penerangan jalan, dan lain sebagainya. Masyarakat Samosir sama sekali tidak membantah perubahan tersebut dan menerimanya, selain itu keramahan mereka menyambut peneliti yang bisa dikatakan orang asing disambut mereka dengan ramah oleh mereka. Hal sederhana seperti ini sudah menunjukkan kesiapan berubah masyarakat Samosir sudah cukup bagus. Memang secara observasi masih ada beberapa sampah yang dibuang sembarang disekitar objek wisata, terkadang pelayanan yang terasa kasar, serta masih mahalnya harga pada beberapa barang, namun secara keseluruhan kesiapan untuk berubah masyarakat Samosir sudah cukup bagus. Selain itu ketika peneliti mewawancarai terkait kesiapan berubah mereka semuanya menjawab mereka mau berubah dan menuju perubahan yang baik. Namun ketika terkait Bali Baru kebanyakan mereka tidak menyukainya sebab beranggapan bahwa Samosir akan berganti nama menjadi Bali Baru tapi mereka memiliki keingin maju seperti Bali tapi asalkan tidak ada perubahan nama pada Kabupaten Samosir.

Self-efficacy masyarakat Samosir menurut peneliti juga tergolong cukup bagus yang terlihat dari observasi peneliti pada masyarakat Samosir dimana mereka rela meluangkan waktu mereka membantu peneliti melakukan penelitian di Samosir yaitu membantu mendokumentasikan foto pelaksanaan penelitian peneliti yang dimana mereka sendiri tidak mengetahui cara menggunakan kamera namun bersikeras belajar menggunakannya. Selain itu secara konteks raga mereka sebenarnya sedang kelelahan karena sedang bekerja tapi tetap bersikap ramah serta rela meluangkan waktunya untuk peneliti, termasuk disini ketika subjek rela meluangkan waktu mereka untuk mengisi skala penelitian dengan senyuman yang ramah serta tulus menjawab pertanyaan peneliti ketika peneliti berbicara dan bertanya sedikit terkait Kabupaten Samosir. Tekad masyarakat Samosir bisa dikatakan sangat bagus juga karena mereka percaya budaya mereka akan tetap terjaga ketika peneliti bertanya kepada subjek penelitian terkait pendapat mereka terhadap "pencampuran budaya", reaksi mereka langsung secara spontan menolakknya dan percaya bisa mempertahankan budaya mereka.

Namun, tentu juga ada beberapa masyarakat yang dari hasil pengamatan peneliti kurang memiliki kesiapan untuk berubah serta selfefficacy yang rendah. Pada mereka yang berusia lanjut yaitu mereka yang tergolong dalam usia dewasa akhir. kepercayaan diri mereka untuk berubah masih tergolong bagus, tapi mereka memiliki self-efficacy yang rendah dimana mereka beranggapan bahwa karena usia mereka yang sudah berkepala 6 dan 7 ini mereka sudah tidak bisa lagi mengejarkan sesuatu hal yang baru, 
mereka sudah tidak paham apa-apa lagi tentang perkembangan zaman ini dan susah mengikuti perubahan. Mereka berpendapat bahwa hal seperti itu hanya anak-anak muda yang bisa melakukannya karena kemampuan mereka sudah menurun drastis. Namun mereka tetap setuju jika Samosir berkembang dan berubah kearah yang baik tapi jika ikut dalam perubahan tersebut mereka tidak percaya akan kemampuan diri mereka yang secara tidak langsung terlihat bahwa efikasi diri mereka mempengaruhi kesiapan mereka untuk berubah. Pada anak yang memasuki usia transisi dewasa awal mereka mempunyai kepercayaan diri yang rendah dimana ketika ditanya mengenai perubahan respon mereka ialah takut tidak bisa menyesuaikan diri, takut perlu belajar banyak hal baru yang dimana pembelajaran yang standar saat ini ia sudah kesulitan memahaminya. Bisa terlihat bahwasannya efikasi diri mereka yang rendah mempengaruhi juga kesiapan mereka untuk berubah.

Berdasarkan uraian di atas, terlihat bahwasannya self-efficacy ini mempunyai hubungan yang positif terhadap readiness for change, dimana jikalau semakin tinggi tingkat self-efficacy masyarakat Samosir maka akan semakin tinggi juga readiness for change masyarakat, begitu pula sebaliknya yaitu semakin rendah tingkat self-efficacy individu maka semakin rendah pula readiness for change pada masyarakat Samosir. Self-efficacy yang tinggi menandakan bahwasannya ia percaya akan kemampuan dirinya bahwasannya bisa melewati efek yang ditimbulkan oleh suatu perubahan dan tidak takut menerima perubahan yang akan hal tersebut secara senada membuat individu tersebut siap untuk berubah.

\section{SIMPULAN}

Hasil uji korelasi Pearson Product Moment pada uji hipotesis penelitian ini menunjukkan bahwasannya ada hubungan yang positif antara Self Efficacy dengan Readiness for Change pada masyarakat Samosir dengan dengan nilai Pearson Correlation sebesar
0,596 dan signifikansi yang berada di bawah 0,05 . Artinya semakin tinggi tingkat Self Efficacy, maka semakin tinggi Readiness for Change masyarakat Samosir. Hasil penelitian ini juga menunjukkan bahwa sumbangan efektif dari Self Efficacy yang memiliki pengaruh sebesar $35,4 \%$ mempengaruhi Readiness for Change. Sedangkan sisanya $64,6 \%$ dipengaruhi oleh faktor lain yang berada diluar penelitian ini. Jadi, memang ada efek dari self-efficacy terhadap readiness for change masyarakat Samosir. Jika masyarakat Samosir mempunyai kepercayaan diri untuk bisa sukses dalam perubahan tersebut maka biasanya ia akan siap untuk berubah. Sebaliknya jika ia tidak mempunyai kepercayaan diri akan berhasil mengikuti atau sukses dalam suatu perubahan, maka aka nada keraguan dalam dirinya yang membuat ia tidak siap untuk berubah karena mungkin sudah nyaman berada di zona nyamannya dan tidak percaya bisa sejahtera atau sukses jika keluar dari zona amannya dan mengikuti perubahan yang ada.

Berdasarkan hasil penelitian yang dilakukan peneliti, ada beberapa saran yang peneliti berikan yaitu adalah diharapkan kepada masyarakat Samosir agar selalu percaya diri terhadap kemampuan yang ada pada dirinya dan mempertahankan sifat senang akan adanya perubahan pada Kabupaten Samosir. Peneliti mengharapkan juga kepada pemerintah Samosir agar tetap terus mempertahankan pelaksanaan berbagai program untuk menyukseskan program Bali Baru ini seperti peningkatan kualitas SDM masyarakat Samosir, sosialisasi lanjut terkait program Bali Baru ini kepada masyarakat Samosir, sosialisasi terkait pentingnya menjaga keaslian Samosir, sosialisasi pentingnya menjaga kebersihan lingkungan, penstabilan harga barang yang ada di Samosir, serta tetap melaksanakan pembangunan dan peningkatan keamanan jalan seperti pembangunan penerangan jalan di pelosok daerah Samosir dan pembagunan pagar pengaman jalan terkhusus di jalan yang menaik keatas sebab agak sedikit berbahaya ketika malam hari tanpa adanya pagar pengaman dan penerangan jalan. 
Terakhir, peneliti berharap kepada peneliti selanjutnya supaya untuk melihat atau meneliti juga faktor-faktor lain yang mempengaruhi variabel Readiness for Change yaitu seperti tingkat motivasi individu, pendidikan, usia dan berbagai variabel lainnya.

\section{REFERENSI}

Angkawijaya, Y. F., Arista, P. D., \& Dewi, D. A. (2017). Berubah, Siapa Takut? Pengaruh Efikasi Diri Terhadap Kesiapan Untuk Berubah Pada Karyawan Di PT TP Tangerang. Jurnal Muara Ilmu Sosial, Humaniora, dan Seni, 1(2), 548-555.

\section{Asmara, C. G. (2019, July 15).}

Pengembangan 10 'Bali Baru', Jokowi Sebut 6 Kendala Utama. Retrieved May 02, 2020, from https://www.cnbcindonesia.com/news/ 20190715181647-4-

85111/pengembangan-10-bali-barujokowi-sebut-6-kendala-utama

Badan Pusat Statistik Kabupaten Samosir. (n.d.). Jumlah Penduduk Samosir Berdasarkan Jenis Kelamin dan Kecamatan Tahun 2015. Retrieved June 14, 2020, from https://samosirkab.bps.go.id/statictable/ 2017/04/18/64/jumlah-penduduksamosir-berdasarkan-jenis-kelamindan-kecamatan-2015.html

Bandura, A. (1997). Self-efficacy: The exercise of control. New York: W.H. Freeman.

Camilleri, M. A. (2018). The Tourism Industry: An Overview. In Travel Marketing, Tourism Economics and the Airline Product (Chapter 1, pp. 3-27). Cham, Switzerland: Springer Nature.

Camilleri, M. A. (2018). The Planning and Development of the Tourism Product. Tourism Planning and Destination
Marketing (Chapter 1, pp. 1-23).

Bingley: Emerald Publishing Limited.

Cunningham, C. E. et al. (2002). Readiness

for organizational change: A longitudinal study of workplace, psychological and behavioral correlates. Journal of Occupational and Organizational Psychology, 75(4), 377-392.

Darmawan, A. H., Azizah, S. (2020, January). Resistance to Change: Causes and Strategies as an Organizational Challenge. In Proceedings of the 5th ASEAN Conference on Psychology, Counselling, and Humanities (ACPCH 2019) (Vol. 395, pp. 49-53).

Desplaces, D. (2005). A Multilevel Approach to Individual Readiness to Change. Journal of Behavioral and Applied Management, 7 (1), 25-39.

Fatima, M., Riaz, A., Mahmood, H. Z. (2020). Linking Employees' ChangeRelated Self-Efficacy, Change Readiness and Commitment to Change. Pakistan Journal of Commerce and Social Sciences, 14(1), 334-367.

Goeldner, C. R., Ritchie, J. R. (2009). Tourism: Principles, Practices, Philosophies. Eleventh Edition. New Jersey: John Wiley \& Sons, Inc.

Holt, D. T., Armenakis, A. A., Feild, H. S., \& Harris, S. G. (2007). Readiness for organizational change the systematic development of scale. The journal of applied behavioral science, 43(2), 232255.

Kompas.com. (2020, January 03). Viral Tagihan Restoran Rp 1,6 Juta di Samosir, Pemilik: Biaya untuk Puluhan Orang. Retrieved July 03, 2020, from https://regional.kompas.com/read/2020/ 01/03/06360071/viral-tagihan-restoranrp-16-juta-di-samosir-pemilik-biayauntuk-puluhan?page $=$ all 
Kompas.com. (2020, February 22). Virus Corona, Bupati Samosir Optimistis Target Wisatawan 2020 Terpenuhi. Retrieved July 03, 2020, from https://travel.kompas.com/read/2020/02 /22/091400027/virus-corona-bupatisamosir-optimistis-target-wisatawan2020-terpenuhi

Kurniawan, S. S. (2019, August 24). Bupati Samosir: Dalam lima tahun mendatang Danau Toba jadi Bali Baru. Retrieved May 02, 2020, from

https://lifestyle.kontan.co.id/news/bupa ti-samosir-dalam-lima-tahunmendatang-danau-toba-jadi-balibaru? page $=$ all

Luszczynska, A., Scholz, U., \& Schwarzer, R. (2005). The General Self-Efficacy Scale: Multicultural Validation Studies. The Journal of Psychology, 139(5), 439-457.

Medanbisnisdaily.com. (2020, March 06). Wabah Virus Corona Tidak Pengaruhi Kunjungan Wisatawan ke Samosir. Retrieved May 02, 2020, from https://medanbisnisdaily.com/news/onli ne/read/2020/03/06/102442/wabah_vir us_corona_tidak_pengaruhi_kunjungan _wisatawan_ke_samosir/

Metwally, D., Palomino, P. R., Metwally, M., \& Gartzia, L. (2019). How Ethical Leadership Shapes Employees' Readiness to Change: The Mediating Role of an Organizational Culture of Effectiveness. Frontiers in Psychology, 10(2493), 1-18.

Peraturan Pemerintah Republik Indonesia Nomor 50 Tahun 2011 Rencana Induk Pembangunan Kepariwisataan Nasional Tahun 2010 - 2025. (02 December 2011). Lembaran Negara Republik Indonesia Tahun 2011 Nomor 125. Jakarta.
Pradhani, B. E., Eliyana, A., \& Istyarini, W. (2016). The Relationship Between Self Efficacy and Readiness for Change: The Mediator Roles of Employee Empowerment. Mediterranean Journal of Social Sciences, 7(3), 201-206.

Pujiono, M., Agustono, B., Aulia, F. (2018). The Managing Tourism Strategy of Danau Toba Based on Local Culture at Samosir Regency. International Journal of Arts Humanities and Social Sciences, 3(2), 1-4.

Purnomo, R. A. (2017). Analisis statistik ekonomi dan bisnis dengan SPSS (cetakan ketiga). Ponorogo: Wade Group.

Raditya, Y., Wibowo, S., Mukti, M. A. (2019). Pengaruh Self Efficacy Dan Perceived Organizational Support Terhadap Resistance To Change Dimediasi Readiness For Change. Sustainable Competitive Advantage-9 (SCA-9) FEB UNSOED, 9(1), 477-490.

Suhartadi, I. (2020). Tokyo Destinasi Wisata Terfavorit Wisatawan Asia saat Imlek 2020. Retrieved July 03, 2020, from https://investor.id/lifestyle/tokyodestinasi-wisata-terfavorit-wisatawanasia-saat-imlek-2020

Urbanus, I N., \& Febianti. (2017). Analisis Dampak Perkembangan Pariwisata Terhadap Perilaku Konsumtif Masyarakat Wilayah Bali Selatan. Jurnal Kepariwisataan Dan Hospitalitas, 1(2), 118-133. 


\section{BIODATA PENULIS}

Wilbert, Fakultas Psikologi, Universitas Prima Indonesia Email: wilbert.huang46@gmail.com.

Christine Tandriani, Fakultas Psikologi, Universitas Prima Indonesia, Medan, Indonesia, Email: ctandriani740@gmail.com.

Winnie Gozali, Fakultas Psikologi, Universitas Prima Indonesia, Medan, Indonesia, Email: winniegozali@gmail.com.

Rianda Elvinawanty, Fakultas Psikologi, Universitas Prima Indonesia, Medan, Indonesia, Email: rianda@unprimdn.ac. 